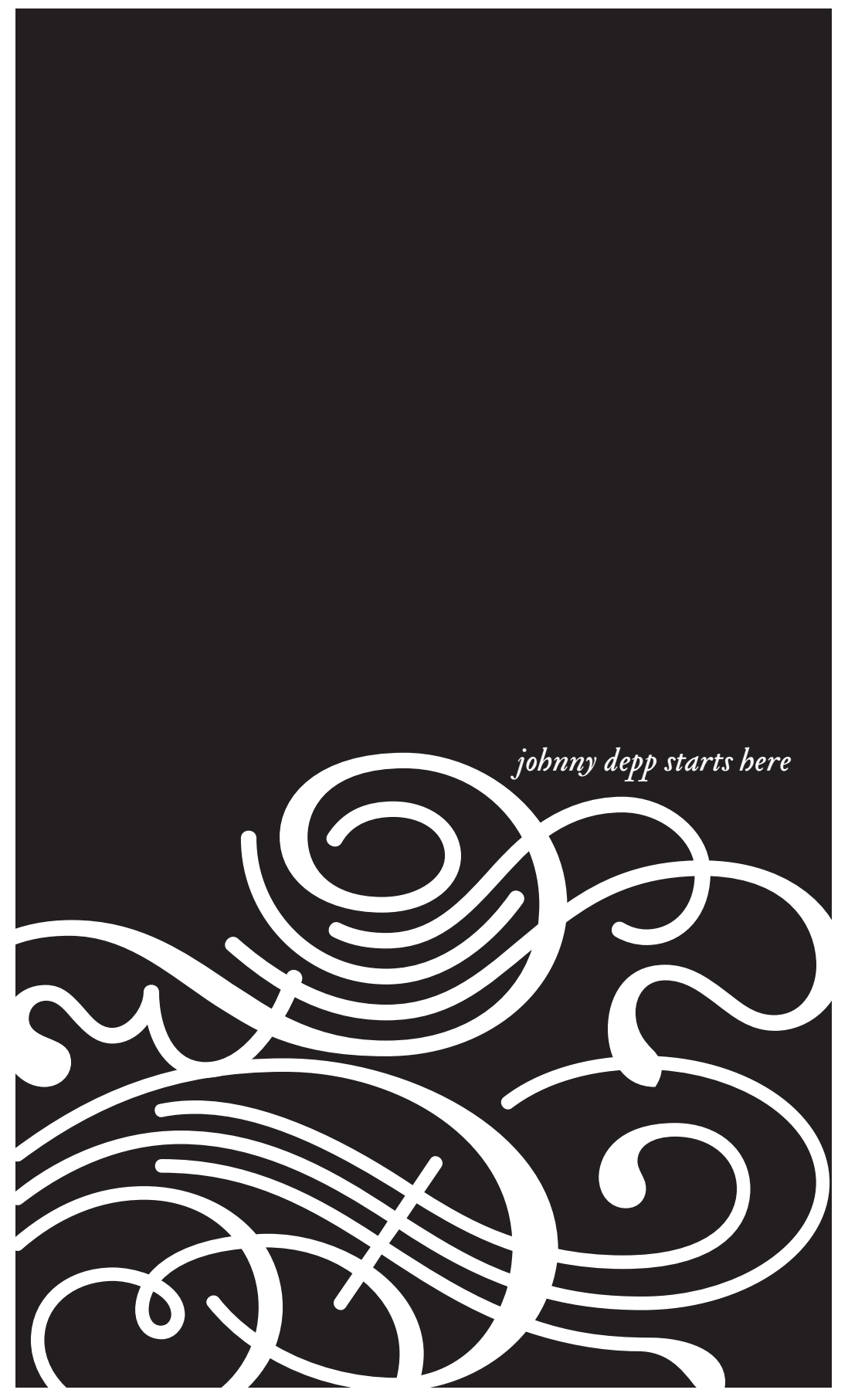




\section{JOHNNY DEPP}

Rutgers University Press

New Brunswick, New Jersey, and London 
Starts Here

Murray Pomerance

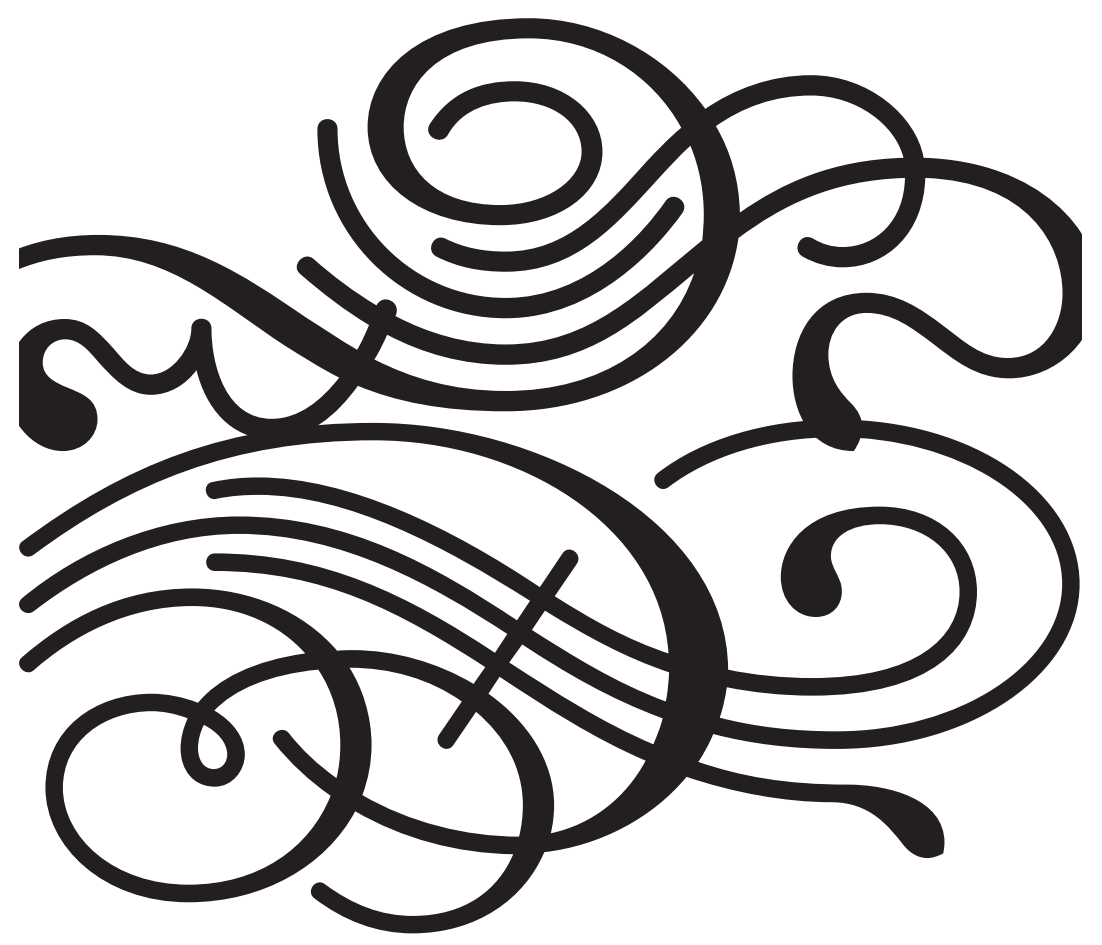


Library of Congress Cataloging-in-Publication Data

Pomerance, Murray, 1946-

Johnny Depp starts here / Murray Pomerance.

p.cm.

Filmography: p.

Includes bibliographical references and index.

ISBN 0-8135-3565-4 (hardcover : alk. paper) - ISBN 0-8135-3566-2 (pbk. : alk. paper)

1. Depp, Johnny-Criticism and interpretation. I. Title.

PN2287.D39P66 2005

$791.4302^{\prime} 8^{\prime} 092-\mathrm{dc} 22$

2004016422

A British Cataloging-in-Publication record for this book is available from the British Library.

Copyright $\odot 2005$ by Murray Pomerance

All rights reserved

No part of this book may be reproduced or utilized in any form or by any means, electronic or mechanical, or by any information storage and retrieval system, without written permission from the publisher. Please contact Rutgers University Press, 100 Joyce Kilmer Avenue, Piscataway, NJ 08854-8099. The only exception to this prohibition is "fair use" as defined by U.S. copyright law. 
for LESLIE FIEDLER (1917-2003)

scholar, teacher, friend, spirit, guide, dreamer 
